\title{
The Role of Islam in the Management and Administration of Brunei Darussalam
}

\author{
Fatin Rabia'tul Adawiyah Mohammed Fareed ${ }^{1 *}$ \\ 1Islamic Civilization and Contemporary Issues, Sultan Omar 'Ali Saifuddien Centre for Islamic Studies (SOASCIS), Universiti Brunei \\ Darussalam
}

ARTICLE INFO

\section{Keywords}

Islam, Manajement and

Administration, Brunei

Darussalam

\section{*Correspondence}

frabiatul2608@gmail.com

\section{Article History}

Received 23 Agustus 2020

Accepted 30 November 2020

Published on-line 30 November 2020

\section{ABSTRACT}

Islam plays an essential role in forming and shaping an Islamic country. Similarly, Brunei Darussalam, an Islamic country, has made every effort to inculcate Islamic values in various aspects of the country's management and administration. This concept paper aims to provide exposure regarding the role of Islam in the management and administration of Brunei Darussalam by describing the history of the arrival of Islam in Brunei Darussalam and the role of Islam in the management and administration of the country. This concept paper uses a qualitative method in the form of a library concerning secondary sources only. The results of the study found that the leadership of the Sultan is a major factor that contributes to the strong application of Islamic teachings in the management and administration of the country, and among the five main aspects that receive the influence of Islamic teachings are aspects of government and administration, administration of Islamic law, religious institutions, Islamic education, and economy. The effect of the application of Islamic teachings has strengthened the country's identity to become an Islamic state.

\section{PENDAHULUAN}

Islam sebagai agama yang syumul mampu membawa kesejahteraan dan kemakmuran kepada rakyat dan juga negara, termasuklah kepada Negara Brunei Darusslam. Negara Brunei Darussalam merupakan sebuah negara Islam yang menjunjung tinggi perintah Allah dan ajaran Nabi Muhammad Sallallahu Alahi Wassalam. Identiti negara Islam ini dicerminkan melalui penerapan dan pengukuhan konsep Melayu Islam Beraja sebagai falsafah kenegaraan dan juga gagasan 'Negara Zikir' sebagai imej negara yang dikehendaki. Ajaran Islam telah lama diserapkan dalam pelbagai jenis aspek dan institusi termasuklah dalam pengurusan dan pentadbiran negara. Persoalannya, 'apakah yang menjadi penyumbang kepada teguhnya penerapan ajaran Islam dalam pengurusan dan pentadbiran Negara Brunei Darussalam?' dan 'apakah aspek-aspek dalam pengurusan dan pentadbiran negara yang menerima pengaruh ajaran Islam?' Kertas konsep ini bertujuan untuk memberikan pendedahan ringkas berkenaan dengan peranan Islam dalam memandu pengurusan dan pentadbiran Negara Brunei Darussalam.

\section{METODE PENELITIAN}

Kertas kerja ini dihasilkan dengan menggunakan kaedah kualitatif berbentuk perpustakaan dengan merujuk buku-buku, jurnal, dan artikel yang relevan daripada perpustakaan tempatan, mahupun secara dalam talian. Pembahasan dalam kertas konsep ini merangkumi sejarah kedatangan Islam di Negara Brunei Darussalam dan peranan Islam dalam pengurusan dan pentadbiran Negara Brunei Darussalam.

\section{PEMBAHASAN}

\subsection{Sejarah Kedatangan Agama Islam di Negara Brunei Darussalam}

Terdapat dua teori yang telah dikenalpasti bagi menggambarkan sejarah kedatangan agama Islam di negara ini, iaitu secara tidak rasmi dan secara rasmi. Pertama, teori secara tidak rasmi dimulai dengan kedatangan para pedagang yang beragama Islam, baik pedagang yang berbangsa China, India mahupun Arab yang singgah di pelabuhan Brunei. Yang mana selain daripada berniaga, para pedagang juga turut mengambil kesempatan untuk berdakwah kepada penduduk tempatan mengenai agama Islam dan kesan daripada dakwah itu terdapat beberapa penduduk yang tertarik dengan agama Islam dan secara diam-diam telah memeluk agama Islam (Latif \& Hassan, 2009). Menurut Jabatan Perdana Menteri Brunei Darussalam (2016), berdasarkan laporan sejarah China, Islam telah ada di Brunei sejak abad ke 10 lagi, atau lebih tepatnya tahun 977 Masihi, ditandai dengan hadirnya pedagang sekaligus 
diplomat Cina yang beragama Islam bernama P'u-Lu-Shieh yang telah diutus oleh kerajaan China. Selain itu, dikisahkan juga bahawa raja Brunei telah menghantar delegasi yang diketuai oleh P'u Ali ke kerajaan China (Jabatan Perdana Menteri Brunei Darussalam, 2016). Latif \& Hassan (2009) serta Azme (2015) turut menambah bahawa salah satu bukti adanya agama Islam pada masa itu ialah dijumpainya batu nisan seorang berbangsa Cina beragama Islam yang bernama Pu Kung Chih-Mu dengan catatan tahun 1264 Masihi. Seterusnya antara abad ke 11 dan 12 baharulah pedagang India dan Arab mula datang ke Brunei bagi memperluaskan lagi penyebaran agama Islam di Brunei (Latif \& Hassan, 2009).

Kedua, iaitu teori secara formal atau rasmi, dimulai dengan pengislaman sultan Brunei yang pertama di Johor, iaitu Awang Alak Betatar dengan nama Islamnya Sultan Muhammad Shah pada abad ke 14 atau tepatnya pada tahun 1368 Masihi, sebelum baginda dikahwinkan dengan puteri Sultan Iskandar yang bernama Puteri Pingai (Latif \& Hassan, 2009). Sejak sultan Brunei memeluk agama Islam, agama Islam mula tersebar secara meluas ke seluruh negara Brunei, sehingga banyak rakyat termasuk keluarga baginda mulai memeluk agama suci ini (Azme, 2015). Menurut Mat Don (1990) setelah Sultan Muhammad Shah memeluk agama Islam, semenjak itulah bermulanya pemerintahan Islam yang beraja di negara ini, yang kemudiannya diwarisi oleh sultan-sultan Brunei setelah baginda. Berdasarkan sejarah kedatangan Islam ini, menunjukkan bahawa kepimpinan sultan merupakan salah satu penyumbang penting kepada kukuhnya penerapan ajaran Islam dalam pengurusan dan pentadbiran Negara Brunei Darussalam.

\subsection{Peranan Islam dalam Pengurusan dan Pentadbiran Negara Brunei Darussalam}

Setelah Sultan Muhammad Shah mangkat pada tahun 1402 Masihi, penyebaran dan pengukuhan agama Islam dilanjutkan lagi oleh sultan-sultan yang seterusnya, hinggalah sekarang Sultan Haji Hassanal Bolkiah turut meneruskan amanah ini dengan mengukuhkan kedudukan Islam dalam pelbagai aspek pengurusan dan pentadbiran negara. Di bawah ini dihuraikan secara ringkas lima aspek utama yang telah menerima pengaruh agama Islam, iaitu aspek sistem pemerintahan dan pentadbiran, pentadbiran undang-undang Islam, institusi keagamaan, pendidikan Islam dan ekonomi.

\subsubsection{Sistem Pemerintahan dan Pentadbiran}

Dari segi sistem pemerintahan dan pentadbiran, Negara Brunei Darussalam merupakan satu-satunya negara di Asia Tenggara yang mengamalkan sistem pemerintahan monarki absolut berdasarkan hukum Islam, (Talib, 2002) iaitu sejak pemerintahan Sultan Muhammad Shah lagi sehinggalah sekarang. Berdasarkan sistem ini, sultan bertanggungjawab dalam menjawat jawatan sebagai perdana menteri Brunei, ketua agama dan ketua kerajaan Brunei. Selain itu, baginda juga memegang jawatan dalam tiga kabinet menteri iaitu Menteri Pertahanan, Menteri Kewangan dan Ekonomi dan Menteri Hal Ehwal Luar Negeri (Ghofur, 2015).

Berkenaan dengan falsafah kenegaraan pula, setelah Brunei mencapai kemerdekaan, Sultan Haji Hassanal Bolkiah telah memperkenalkan falsafah Melayu Islam Beraja (MIB) sebagai ideologi negara. Meskipun falsafah ini telah lama diamalkan oleh pemerintahan Brunei, iaitu sejak pemerintahan Sultan Muhammad Shah lagi (Mat Don, 1990), akan tetapi falsafah ini perlu ditekankan lagi secara kukuh dengan tujuan untuk meningkatkan kesetiaan rakyat terhadap raja dan negara (Talib, 2002). Falsafah ini secara rasminya telah diisytiharkan oleh Kebawah Duli Yang Maha Mulia Paduka Seri Baginda Sultan dan Yang Dipertuan Negara Brunei Darussalam pada 1 Januari 1984, seperti yang terkandung di dalam titah pengisytiharan Kemerdekaan Negara Brunei Darussalam :

"Negara Brunei Darussalam adalah dan dengan izin serta limpah kurnia Allah Subhanahu wa Ta'ala akan untuk selama-lamanya kekal menjadi sebuah Negara Melayu Islam Beraja yang merdeka, berdaulat dan demokratik, bersendikan kepada ajaran-ajaran agama Islam menurut Ahli Sunnah wal Jama'ah dan dengan berasaskan keadilan amanah dan kebebasan."

Sejak pengisytiharan tersebut, falsafah ini telah menjadi dasar penting dalam legitimasi kesultanan, sekaligus mengangkat Islam sebagai agama rasmi negara dan menjamin hak-hak dari masyarakat etnik Melayu serta membenarkan garis keturunan sultan sebagai sistem pemerintahan yang relevan (Talib, 2013). Melayong (2012) turut menyatakan bahawa penetapan MIB sebagai falsafah negara ini ialah kerana baginda sultan menyedari bahawa meskipun Brunei telah merdeka, namun proses penjajahan moden tetap akan berlaku dalam era globalisasi ini dan pada masa kini penjajahan yang dilakukan bukanlah dari segi penjajahan wilayah dan politik lagi, akan tetapi melibatkan aspek ekonomi, bahasa, sosial, mental, keagamaan dan kebudayaan, yang disebut juga dengan imperialisma budaya. Oleh kerana itulah, baginda kukuh mempertahankan falsafah MIB ini, kerana ianya merupakan satu-satunya lambang yang menggambarkan identiti sebenar negara dan bangsa ini, yang mana rakyatnya ialah berbangsa melayu yang terdiri dari tujuh puak, agama rasmi negaranya ialah agama Islam dan corak pemerintahannya ialah sistem beraja. Ini kerana jika falsafah MIB ini tiada atau dihapuskan, maka identiti Negara Brunei Darussalam pun akan turut lenyap.

Selain daripada mengamalkan ideologi MIB sebagai falsafah negara, baginda sultan juga telah berhasrat untuk menjadikan negara ini sebagai sebuah Negara Zikir. Sebagaimana titah baginda sempena Hari Raya 'Aidiladha pada tahun 1428 Hijrah bersamaan dengan tahun 2007 Masihi,

"Beta insya' Allah, akan terus berazam untuk menjadikan Brunei Darussalam sebuah 'Negara Zikir' yang sentiasa mengagungkan Allah, supaya kita selalu berada dalam perhatian dan pemeliharaan-Nya, sesuai dengan janji-Nya di dalam surah al-Baqarah ayat 152, tafsirnya "Kamu ingat Aku, nescaya Aku akan mengingati kamu pula."

Secara umum, Negara Zikir ini bermaksud sebuah negara, yang mana rakyatnya sentiasa mengingati Allah dan mengamalkan segala ajaran Islam dalam setiap perkara yang dirancang dan dilaksanakan. Manakala bagi mewujudkan Negara Zikir ini pula bukanlah mudah, melainkan perlu kepada usaha-usaha yang dijalankan secara konsisten oleh seluruh rakyat. Terdapat beberapa usaha dan strategi yang telah dijalankan dalam usaha merealisasikan gagasan Negara Zikir ini, antaranya ialah membudayakan pembacaan al-Qur'an, baik di institusi kerajaan, persekolahan mahupun di kalangan masyarakat; selain itu pembinaan masjidmasjid juga telah giat dilaksanakan bagi kemudahan masyarakat untuk beribadah dan menjalankan aktiviti keagamaan; dijalankannya pelaksanaan perintah kanun hukuman jenayah syariah dan juga dikeluarkannya perintah pendidikan ugama wajib yang mewajibkan semua kanak-kanak untuk mengikuti persekolahan ugama. Secara langsung gagasan Negara Zikir ini turut berfungsi sebagai pelengkap dan penguat bagi falsafah MIB.

\subsubsection{Pentadbiran Undang-Undang Islam}

Dari segi pentadbiran undang-undang Islam pula, negara ini telah mengalami tiga fasa transformasi. Pertama ialah pada awal pemerintahan sultan-sultan Brunei, yang mana undang-undang yang digunakan pada masa itu ialah Hukum Kanun Brunei, Syariat Islam, Adat Resam dan Adat Istiadat Melayu. Undang-undang inilah yang kemudiannya diwarisi oleh sultan-sultan Brunei selepas Sultan Muhammad Hasan sehinggalah Sultan Hashim Jalilul Alam Aqamaddin (Sultan Brunei yang ke-25) (Daud, 1990). 
Kedua iaitu pada zaman pemerintahan residen, yang mana terdapat empat pentadbiran undang-undang Islam yang telah dibentuk, iaitu Muhammadan Law 1912, Muhammadan Marriage and Divorce 1913, Courts Enactment 1951 dan Undang-Undang Majlis Ugama dan Mahkamah-mahkamah Kadi 1955. Undang-undang ini lebih kemas dan bersifat menyeluruh meliputi semua bidang yang boleh dikenakan kepada semua orang Islam di negara ini. Ekoran daripada penguatkuasaan ini juga, Mahkamah Kadi telah mempunyai sistem dan struktur pentadbiran tersendiri dan tidak lagi berada di bawah pentadbiran Mahkamah Brunei. Berdasarkan undang-undang tersebut mahkamah telah disusun semula menjadi Mahkamah-Mahkamah Kadi, Mahkamah Kadi Besar dan Jawatankuasa Kehakiman (Tamit, 2010).

Ketiga ialah setelah Brunei mencapai kemerdekaan. Pada tahun 2001 Mahkamah Syariah telah ditubuhkan dan dengan tertubuhnya Mahkamah Syariah itu, struktur mahkamah juga telah berubah, yang mana Mahkamah Kadi menjadi Mahkamah Rendah Syariah, Mahkamah Kadi Besar menjadi Mahkamah Tinggi Syariah dan Jawatankuasa Kehakiman menjadi Mahkamah Rayuan Syariah. Pada masa yang sama, Undang-Undang Keluarga Islam juga telah dibentuk dengan penggubalan Perintah Darurat (Undang-Undang Keluarga Islam), 1999 dan undang-undang yang lain, yang akan ditadbir oleh Mahkamah Syariah iaitu undangundang keterangan, acara mal dan undang-undang jenayah dan acaranya. Bidang kuasa Mahkamah Syariah juga turut diperluaskan kepada membicarakan permohonan pengangkatan kanak-kanak dalam Islam dan permohonan perintah pajak gadai (Tuah, 2009). Pada 22 Oktober 2013, satu kemajuan baharu telah dicapai dengan diwartakannya Perintah Kanun Hukuman Jenayah Syar'iah 2013, yang dilaksanakan secara bertahap dalam tiga fasa dan telah dilaksanakan sepenuhnya pada 3 April 2019.

\subsubsection{Institusi Keagamaan}

Pada tahun 1948, badan yang bertanggungjawab dalam melindungi agama Islam dan segala hal yang berkaitan dengannya dinamakan dengan 'Penasihat Ugama Islam'. Pada tahun 1954 pula, Jabatan Hal Ehwal Ugama, Adat Istiadat dan Kebajikan telah ditubuhkan dan kemudian Jabatan Hal Ehwal Ugama telah diasingkan daripada Adat Istiadat dan Kebajikan sebagai satu jabatan setelah Perlembagaan Negeri Brunei 1959 dikuatkuasakan. Pada tahun 1986 baharulah Jabatan Hal Ehwal Ugama dinaiktarafkan menjadi Kementerian Hal Ehwal Ugama (Kementerian Hal Ehwal Ugama, 2012).

Di bawah kementerian ini, terdapat lapan buah jabatan dan dua buah institusi pendidikan yang telah ditubuhkan, yang mana kesemuanya mempunyai peranan masing-masing dalam mempertahankan kedudukan Islam di negara ini. Lapan buah jabatan dan dua buah intitusi pendidikan tersebut ialah Jabatan Majlis Ugama Islam, Jabatan Pentadbiran, Jabatan Hal Ehwal Syariah, Jabatan Hal Ehwal Masjid, Pusat Da'wah Islamiah, Unit Perundangan Islam, Jabatan Urusan Haji, Jabatan Pengajian Islam, Kolej Universiti Perguruan Ugama Seri Begawan (KUPU SB) dan Institut Tahfiz al-Quran Sultan Haji Hassanal Bolkiah (ITQSHHB) (Kementerian Hal Ehwal Ugama, 2012).

Di samping itu, bagi mencegah daripada berlakunya penyimpangan dalam memberikan penerangan mengenai ajaran Islam, Majlis Ugama Islam telah mengeluarkan tauliah kebenaran mengajar ugama bagi individu yang berniat untuk mengajar Al-Qur'an, pengetahuan agama atau memberikan ceramah keagamaan. Tauliah ini dikeluarkan selaras dengan kehendak Perintah Kanun Hukuman Jenayah Syar'iah 2013 yang memperuntukkan seperti berikut (Permohon Tauliah Kebenaran Mengajar AlQuran/Ugama/Berceramah Ugama, Majlis Ugama Islam Brunei) :

"229 (1). Mana-mana orang yang mengajar sesuatu perkara yang berkaitan dengan ugama Islam tanpa kebenaran bertulis daripada Majlis adalah melakukan suatu kesalahan dan hendaklah jika sabit kesalahan dikenakan suatu denda tidak melebihi \$8,000, dihukum penjara selama suatu tempoh tidak melebihi 2 tahun atau kedua-duanya sekali."

Tambahan lagi pada masa kini, banyak organisasi swasta yang telah ditubuhkan dengan tujuan untuk memberikan pengajaran ugama, baik dalam memberikan ceramah keagamaan mahupun memberikan pengajaran Al-Qur'an, yang memerlukan setiap tenaga pengajar untuk mendapatkan tauliah kebenaran mengajar ugama. Organisasi swasta tersebut antaranya ialah seperti, $\mathrm{Al}$ Minhaaj Centre, Al-Huffaz Management, Nadi Quranic Learning Centre, Al-Muyassar dan sebagainya. Selain itu, terdapat juga pusatpusat tuisyen yang menawarkan pengajaran al-Qur'an, mata pelajaran Pengetahuan Ugama Islam dan Bahasa Arab.

\subsubsection{Pendidikan Islam}

Penyebaran pendidikan Islam telah bermula sejak kedatangan Islam di negara ini lagi. Pada masa itu pendidikan Islam masih diajarkan dengan sistem tradisional atau secara tidak formal, yang mana ianya diajarkan oleh orang perseorangan seperti mubaligh Islam, imam atau khatib, baik yang berasal dari luar negeri mahupun penduduk tempatan di rumah-rumah, balai-balai dan masjid-masjid (Ahmad, \& Salleh, 2015; Kambar, 2013). Semasa pemerintahan Residen British, sistem pendidikan Islam secara tradisional ini masih lagi diteruskan sehinggalah pada tahun 1914. Setelah itu pemerintahan British telah mula menjalankan sistem pendidikan sekular secara rasmi, yang telah menyebabkan perkembangan pendidikan Islam semakin ketinggalan (Kambar, 2013). Bagi mencegah kemerosotan pendidikan Islam, pada tahun 1931 pendidikan Islam telah dimasukkan dalam sistem persekolahan Melayu sebagai satu mata pelajaran (Mail, 2007).

Bagi mengukuhkan lagi kedudukan pendidikan Islam di negara ini, pada tahun 1956 Sultan Haji Omar Ali Saifuddien telah menubuhkan tujuh buah sekolah rendah ugama yang beroperasi pada waktu petang sahaja (Kambar, 2013) bagi menawarkan pendidikan Islam di peringkat rendah. Seterusnya sistem sekolah agama ini kemudiannya dilaratkan ke semua Sekolah Melayu dan Inggeris (Kambar, 2013). Hingga kini Negara Brunei Darussalam telah mendirikan sebanyak 144 buah sekolah rendah ugama, di Daerah Brunei dan Muara terdapat sebanyak 86 buah sekolah rendah ugama, 30 buah di Daerah Tutong, 20 buah di Daerah Belait dan sebanyak 11 buah di Daerah Temburong. Namun hanya sebanyak 50 buah sekolah yang merupakan bangunan kekal bagi sekolah rendah ugama, manakala selebihnya lagi iaitu 94 buah merupakan bangunan gunasama.

Selain itu, satu undang-undang khas juga telah digubal yang dinamakan dengan Perintah Pendidikan Ugama Wajib 2013 yang berkuatkuasa mulai 1 Julai 2013. Perintah ini bertujuan agar tiada lagi kanak-kanak Islam yang keciciran dalam mempelajari pendidikan Islam di peringkat persekolahan ugama (Apong, 2013).

Selain daripada sekolah rendah ugama, sekolah Arab dan Tahfiz juga turut dibangun bagi mengukuhkan lagi pendidikan Islam. Setakat ini terdapat tujuh buah sekolah Arab yang telah dibina di setiap daerah (Kementerian Hal Ehwal Ugama, t.t). Institut Tahfiz Al-Quran Sultan Haji Hassanal Bolkiah (ITQSHHB) pula telah ditubuhkan pada 1 Januari 1993, dengan menawarkan pengajian kepada lelaki dan juga perempuan, yang bertujuan untuk melahirkan para Hafiz Al-Quran (Kementerian Hal Ehwal Ugama, t.t).

Selain daripada sekolah rendah ugama, sekolah Arab dan institut tahfiz, dalam sekolah rendah dan sekolah menengah kerajaan, mata pelajaran Pengetahuan Ugama Islam juga turut diajarkan. Namun di peringkat sekolah rendah, mata pelajaran Pengetahuan Ugama Islam tidak dimasukkan dalam peperiksaan Penilaian Sekolah Rendah (PSR), akan tetapi di peringkat sekolah menengah 
ianya merupakan satu mata pelajaran teras yang turut dinilai dalam Peperiksaan Brunei Cambridge O Level. Manakala pada peringkat pra universiti pula, mata pelajaran Pengetahuan Ugama Islam ini merupakan mata pelajaran pilihan yang dibahagikan kepada dua mata pelajaran, iaitu Syariah dan Usuluddin. Keduanya turut dinilai dalam Peperiksaan Brunei Cambridge A Level.

Dari segi institusi pengajian tinggi pula, negara ini mempunyai sebanyak 12 buah institusi pengajian tinggi, enam buah merupakan institusi kerajaan manakala selebihnya lagi merupakan institusi swasta. Namun hanya tiga buah institusi yang menawarkan kursus pendidikan Islam di peringkat pengajian tinggi, yang mana kesemuanya merupakan institusi kerajaan iaitu Kolej Universiti Perguruan Ugama Seri Begawan (KUPU SB), Universiti Islam Sultan Sharif Ali (UNISSA) dan Universiti Brunei Darussalam (UBD).

Selain daripada sekolah-sekolah kerajaan, terdapat juga sekolah swasta berteraskan Islam yang menyediakan pendidikan Islam, seperti Sekolah Al-Falaah, Sekolah Rendah IQRA, Sekolah Alif Sdn Bhd, Miftah An-Nur International School dan sebagainya yang menawarkan pendidikan Islam dari peringkat tadika hingga rendah.

\subsubsection{Ekonomi}

Dari segi ekonomi pula, terdapat lima aspek yang menjadi mercu perkembangan ekonomi Islam di negara ini. Pertama, dalam aspek institusi kewangan Islam, yang mana Brunei telah mempunyai dua institusi kewangan Islam yang memberikan perkhidmatan bebas riba, iaitu Tabung Amanah Islam Brunei (TAIB) dan Bank Islam Brunei Darussalam (BIBD). Kedua ialah Sukuk Al-Ijarah, yang telah dilancarkan dalam tempoh jangka pendek oleh kerajaan Brunei pada 6 April 2006 (Successful issuances of Brunei Darussalam government short-term Sukuk Al-Ijarah Securities, 2018). Ketiga ialah zakat, yang bertujuan untuk mengurangkan kadar kemiskinan yang berlaku dalam sesebuah negara. Di Brunei Darussalam, institusi yang bertanggungjawab dalam menguruskan kutipan dan agihan zakat ialah Majlis Ugama Islam Brunei (MUIB), di bawah Kementerian Hal Ehwal Ugama. Di samping itu, di negara ini hanya enam golongan yang menerima agihan zakat, iaitu golongan fakir, miskin, Amil, Muallaf, alGharimin dan Ibnu Sabil. Manakala dua golongan lagi, iaitu al-Riqab dan Fisabilillah pula tidak ada dalam kategori masyarakat Brunei Darussalam (Febrianti, 2011 dan Abdullah, 2015).

Keempat ialah industri halal. Dalam rangka memajukan lagi perkembangan ekonomi negara, baginda Sultan juga turut berhasrat untuk menjadikan negara ini sebagai 'hub halal global'. Bagi menjayakan perancangan ini, sebuah jenama telah dilancarkan yang dikenali dengan 'Jenama Brunei Halal' atau 'Brunei Halal Brand'. Jenama Brunei Halal merupakan satu projek utama kerajaan yang merupakan inisiatif Kementerian Perindustrian dan Sumber-Sumber Utama dengan kerjasama Kementerian Kesihatan, Kementerian Hal Ehwal Ugama dan Majlis Ugama Islam Brunei (Julaini \& Idris, 2010). Kelima pula ialah pengharaman arak dan larangan merokok

\section{KESIMPULAN}

Secara keseluruhannya, bagi persoalan kajian yang pertama, didapati bahawa kepimpinan sultan atau pemerintah merupakan faktor utama yang menyumbang kepada kukuhnya penerapan ajaran Islam dalam pengurusan dan pentadbiran negara. Manakala bagi persoalan yang kedua pula, hasil kajian menunjukkan bahawa secara khususnya terdapat lima aspek utama dalam pengurusan dan pentadbiran negara yang telah menerima pengaruh agama Islam, iaitu aspek sistem pemerintahan dan pentadbiran, pentadbiran undang-undang Islam, institusi keagamaan, pendidikan Islam dan ekonomi. Dengan menerapkan ajaran Islam dalam beberapa aspek pengurusan dan pentadbiran negara ini ianya telah mengukuhkan lagi kedudukan Islam di negara ini.

\section{Daftar Pustaka}

Abdullah, R. (2015). Zakat Management in Brunei Darussalam. Bandar Seri Begawan, Brunei Darussalam : UNISSA Press.

Ahmad, S. S. H., \& Salleh, M. S. (2015). Dasar dan strategi pembangunan negara zikir. UNISSA Press.Brunei Darussalam : UNISSA Press.

Apong, Y. (2013). Perintah Pendidikan Ugama Wajib 2012 : Sinar Harapan Negara Zikir (Siri Monograf Pendidikan Islam: bilangan 5). Bandar Seri Begawan, Brunei Darussalam : Pusat Penerbitan Kolej Universiti Perguruan Ugama Seri Begawan.

Azme, B. H. M. (2015). Islam Wasatiyah: Pengalaman Negara Brunei Darussalam. http://idr.uin-antasari.ac.id/2/

Daud, F.D.M., (1990). Kerajaan Islam di Brunei : Suatu Tinjauan Sejarah. Jurnal Pusaka, 3, 27-34.

Febrianti. (2011). Praktek Pengelolaan Zakat di Negara Muslim (Studi pada Negara Brunei Darussalam). (Disertasi sarjana tidak diterbitkan). Universitas Islam Negeri Syarif Hidayatullah.

http://repository.uinjkt.ac.id/dspace/bitstream/123456789/1640/1/FEBRIANTI-FSH.PDF

Ghofur, A. (2016). Islam dan Politik di Brunei Darussalam (suatu Tinjauan Sosio-historis). TOLERANSI: Media Ilmiah Komunikasi Umat Beragama, 7(1), 53-69. http://ejournal.uin-suska.ac.id/index.php/toleransi/article/view/1421/1229

Jabatan Perdana Menteri Brunei Darussalam. (2016). Islamic Tourism Brunei Darussalam. Bandar Seri Begawan : The Government Printing Department, Prime Minister's Office Brunei Darussalam. https://bruneitourism.com/wpcontent/uploads/2018/10/Islamic-Tourism-Brunei-Darussalam.pdf

Julaini, S. S. \& Idris, N. (2010). Brunei Halal Brand. Brunei Today, 12(3), 3-9.

Kambar, M. (2013). Dasar Pendidikan Islam di Negara Brunei Darussalam (1950-2007). Brunei Darussalam : Dewan Bahasa dan Pustaka, Kementerian Kebudayaan, Belia dan Sukan.

Kementerian Hal Ehwal Ugama Brunei Darussalam. (t.t). Senarai Sekolah Arab. http://www.kheu.gov.bn/SitePages/Senarai\%20Sekolah\%20Arab.aspx

Kementerian Hal Ehwal Ugama Brunei Darussalam. (2012). 50 Tahun dalam Ristaan Perkhidmatan Hal Ehwal Ugama Negara Brunei Darussalam (1959-2009). Brunei Darussalam : Kementerian Hal Ehwal Ugama.

Mail, H. A. A. B. H. (2007). Pendidikan Agama Islam Brunei Darussalam Pramerdeka: Pengalaman, Tranformasi dan Cabaran. Beriga, 96, 3-24.

https://www.researchgate.net/publication/313313610_Pendidikan_Agama_Islam_Brunei_Darussalam_Pramerdeka_Pengala man_Tranformasi_dan_Cabaran

Mat Don, O. (1990). Pentadbiran Brunei Darussalam : Suatu Tinjaun Ringkas. Jurnal Pusaka, 3, 5-13.

Melayong, M. H. M (2012). Brunei dalam Lintasan Sejarah. Brunei Darussalam: Jabatan Penerangan, Jabatan Perdana Menteri.

Latif, M.A. \& Hassan, Z. (2009). Brunei Setelah Menerima Islam. Jurnal Pusaka, 17, 44-50. http://www.historycentre.gov.bn/Themed/Agama\%20Islam\%20PDF.pdf 
Successful Issuances of Brunei Darussalam Government Short-Term Sukuk Al-Ijarah Securities. (2018). Borneo Bulletin. https://borneobulletin.com.bn/successful-issuances-of-brunei-darussalam-government-short-term-sukuk-al-ijarahsecurities-9/

Talib, N. S. (2002). A Resilient Monarchy: The Sultanate of Brunei and Regime Legitimacy in An Era of Democratic Nation-States. New Zealand Journal of Asian Studie,s 4(2), 134-147. http://www.nzasia.org.nz/downloads/NZJAS-Dec02/4.2 8.pdf

Talib, N. S. (2013). Brunei Darussalam: Kesultanan Absolut dan Negara Modern. Kyoto Review of Southeast Asia, Monarchies in Southeast Asia, 13, 1-9. https://kyotoreview.org/issue-13/brunei-darussalam-kesultanan-absolut-dan-negara-modern/

Tamit, S. (2010). Pentadbiran Undang-Undang Islam Negara Brunei Darussalam. Dalam Zaman British dalam 100 Tahun Hubungan Brunei-British 1906-2006 : Kumpulan Kertas Kerja Seminar Sejarah Brunei III (Hlm : 269-294). Bandar Seri Begawan, Brunei Darussalam : Pusat Sejarah Brunei, Kementerian Kebudayaan, Belia dan Sukan.

Tuah, D. Z. (2009). Perkembangan pentadbiran mahkamah syariah di negara Brunei Darussalam/Dy Zainab binti Awg Haji Tuah (Doctoral dissertation, University of Malaya). 